\title{
Precipitation Behavior of Second Phases during Isothermal Oxidation of Hastelloy C-2000 Alloys
}

\author{
Yuan Liang, Hu Rui, Zhang Tiebang, Xue Xiangyi, Li Jinshan \\ State Key Laboratory of Solidification Processing, Northwestern Polytechnical University, Xi'an 710072, China
}

\begin{abstract}
The precipitation behavior of the second phase in Hastelloy C-2000 alloy matrix was studied after isothermal oxidation at $800{ }^{\circ} \mathrm{C}$ for $100 \mathrm{~h}$ in air. Mo-rich phase was precipitated in the alloy matrix after oxidation. According to the determination Mo-rich phase with diamond cubic structure is $\mathrm{Mo}_{3} \mathrm{Ni}_{3} \mathrm{C}$ type carbide. Morphology characteristics of Mo-rich phase with both no-continuous and continuous irregular strip are presented along grain boundaries and in matrix, respectively. However, some variation of morphologies will take place at both grains and grain boundaries after deep etching, i.e. a large number of white flocculent structure are distributed along grain boundaries, and the corrosion pits with a diamond structure appear in intragranular. Ni-rich and $\mathrm{Cr}$-rich areas are more easily corroded during deep etching due to a more negative electrode potential in the areas.
\end{abstract}

Key words: oxidation; Mo-rich phase; $\mathrm{Mo}_{3} \mathrm{Ni}_{3} \mathrm{C}$ type carbide; grain boundary; potential

As a new development of Ni-Cr-Mo-based superalloy, C-2000 alloy has been widely used as oil chemical pipelines, coal chemical dust filter, energy and electricity heat exchanger tubes for its excellent corrosion resistance in oxidizing and reducing media. However, superior oxidation resistance is required under the service condition. Therefore, the high temperature oxidation performance of the alloy is an important index for service life ${ }^{[1-7]}$.

The oxidation of an alloy at high temperatures is equivalent to the long-term aging for the alloy, i.e. the precipitation of different phases would take place in the alloy matrix after oxidation. It is well known that various carbides, TCP phases and ordering phases precipitate in both grain boundaries and grains, and their evolution has been extensively reported in the temperature range of $650 \sim 900{ }^{\circ} \mathrm{C}$ in literatures ${ }^{[8-11]}$. The influence of the precipitation of second phases on the performance of the alloy is quite obvious. Tawancy et al. ${ }^{[12]}$ reported that the $\mathrm{Pt}_{2} \mathrm{Mo}$ superlattice phase in $\mathrm{Ni}-\mathrm{Cr}$-Mo alloy could lead to an increase in yield strength of 2 3 fold over the solution strengthened alloy. Casales et al. ${ }^{[13]}$ showed that the corrosion resistance of alloy 600 was associated with semi-continuous to continuous carbides at grain boundaries, with few intergranular carbides. Sahlaoui et al. ${ }^{[14]}$ found that chromium concentration evolution and chromium depleted zones appeared resulting from carbides precipitation during aging of the $\mathrm{Ni}-\mathrm{Cr}-\mathrm{Fe}$ alloys at the carbide-matrix interface and near the grain boundaries intergranular, respectively, so that corrosion resistance properties of alloys were greatly affected. Berthod et al. ${ }^{[15]}$ reported that the dissolution of carbides led to the formation of non-carbides areas in alloy matrix under oxide scales during high temperature oxidation, which would result in both deterioration of mechanical property and decrease of oxidation resistance.

Owing to low carbon contents of C-2000 alloy, which can be seen as a non-carbon alloy, the precipitation behavior of carbides in C-2000 is rarely considered in the service circumstance. Yang et al. ${ }^{[16]}$ studied the oxidation characteristic of $\mathrm{Ni}-\mathrm{Cr}-\mathrm{Mo}$ alloy from $600{ }^{\circ} \mathrm{C}$ to $1000{ }^{\circ} \mathrm{C}$ by isothermal oxidation, but the precipitation behavior of second phases in matrix during oxidation was not considered by

Received date: December 14, 2015

Foundation item: National High Technology Research and Development Program of China ("863" Program)(2013AA031004)

Corresponding author: Hu Rui, Professor, State Key Laboratory of Solidification Processing, Northwestern Polytechnical University, Xi'an 710072, P. R. China, Tel 0086-29-88491764, E-mail: rhu@ nwpu.edu.cn

Copyright (C) 2016, Northwest Institute for Nonferrous Metal Research. Published by Elsevier BV. All rights reserved. 
authors. However, the precipitation of minute traces of carbides would take place even a low carbon contents during isothermal oxidation temperature of C-2000. As corrosion resistant alloy, the properties of high temperature oxidation of C-2000 are also an important indicator during the service process. It was just to meet the precipitation conditions of second phases in C-2000 alloy during oxidizing atmosphere at $600 \sim 800{ }^{\circ} \mathrm{C}$. Moreover, the precipitation position, the morphology and the distribution of second phases will affect high temperature oxidation properties of alloys once they are precipitated in matrix. Therefore, the significance of the precipitation behavior of second phases in C-2000 will become evident for the application of the alloy. The purpose of this paper is to investigate the precipitation behavior of phase in C-2000 alloy matrix during isothermal oxidation at $800{ }^{\circ} \mathrm{C}$ for $100 \mathrm{~h}$ in air.

\section{Experiment}

The material used in this study was Hastelloy C-2000 alloy supplied by Haynes International Company, whose composition (wt \%) is $22.81 \mathrm{Cr}, 15.55 \mathrm{Mo}, 1.48 \mathrm{Cu}, 0.87 \mathrm{Fe}, 0.24 \mathrm{Al}$, $0.22 \mathrm{Mn}, 0.08 \mathrm{Co}, 0.007 \mathrm{P}, 0.003 \mathrm{~S},<0.02 \mathrm{Si}, 0.001 \mathrm{C}$ and Bal. Ni. The oxidation tests were carried out at $800{ }^{\circ} \mathrm{C}$ for $100 \mathrm{~h}$ in air. After oxidation, oxide scales on surfaces of specimens were completely polished by silicon carbide sandpaper, and then the specimen surfaces were wet-polished up to 2000 grit with a series of $\mathrm{SiC}$ sandpapers, and polished successively with 1.0, and $0.5 \mu \mathrm{m}$ alumina powder suspensions, and then ultrasonicated for $30 \mathrm{~min}$.

The precipitation behavior of second phases in alloy matrix was examined by X-ray diffraction (XRD). Morphologies and chemical compositions of second phases were analyzed by scanning electron microscope (SEM) with energy dispersive $\mathrm{X}$-ray spectrometer (EDS). Transmission electron microscope (TEM) was used to determine structural characteristics of second phases. In addition, samples were etched using $\mathrm{HCl}$ and $\mathrm{H}_{2} \mathrm{O}_{2}$ solution in order to further study morphologies of precipitation phases.

\section{Results and Discussion}

\subsection{SEM-BSE images of alloy matrix after oxidation}

The morphologies and the element line scanning of second phases in alloy matrix after oxidation are displayed in Fig.1. Second phases present the no-continuous and continuous irregular strips in grains and grain boundaries, respectively. It is well known that defect density in grain boundaries is higher than that in grains, which results in the formation of continuous gradient in grain boundaries. Meanwhile, dislocations and vacancies are main types of defects in grains, which is consistent with the viewpoint of Zheng et al. ${ }^{[17,18]}$. Moreover, dark-gray fuzzy spots also emerge in local grains. It is well known that the backscattered electron yield increases with increasing of atomic number. Atomic number fraction of both $\mathrm{Ni}$ and $\mathrm{Cr}$ elements are less than that of Mo element; therefore, it can be speculated from BSE that both second phases and dark-gray fuzzy spots may be Mo-rich phases and areas of Ni-rich and Cr-rich, respectively. This is consistent with the results of both EDS spectra and the line scanning. Meanwhile, the size of Mo-rich phases was measured by a statistical method, and its size is approximately $4 \sim 5 \mu \mathrm{m}$ (Fig.1b). It can be found from XRD (Fig.2) that the position and the width of diffraction peaks are not dramatically changed compared with the original alloy matrix. Due to volume fractions of phases less than detective range of X-ray, diffraction peaks of Mo-rich phases do not appear, either.

The oxidation of an alloy at high temperatures is equivalent to the long-term aging, namely temperature and time provide thermodynamics and kinetics conditions for the precipitation of second phases. It is well known that grain boundary is fast diffusion paths channels of elements ${ }^{[19]}$. Mo atoms would quickly migrate from the alloy matrix to grain boundaries with volatilizing Mo oxides; as a result, a concentration gradient of Mo is formed from grains to grain boundaries. This moment, other major alloying elements such as $\mathrm{Ni}$ and $\mathrm{Cr}$ will also start to diffuse toward the interface between alloy and gas, and $\mathrm{Ni}$ and $\mathrm{Cr}$ oxide scales with an excellent protection performance are formed on the surface of the alloy with prolonging of oxidation time. Consequently, the evaporation rate of the Mo-oxides is greatly reduced, and gathering of Mo atoms begins to occur at grain boundaries when the evaporation rate of Mo oxides is lower than the migration rate of Mo atoms from matrix to grain boundary. Moreover, Mo atoms also may

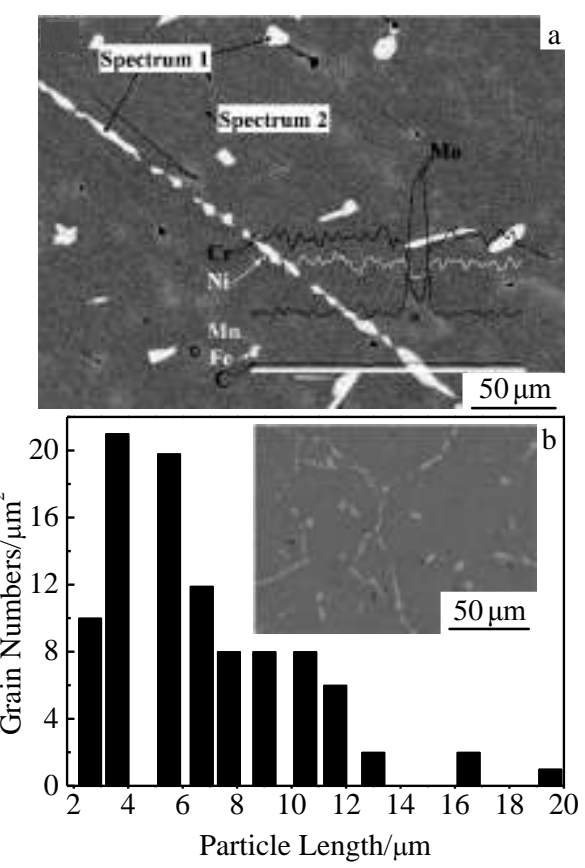

Fig.1 SEM-BSE image and elements line scanning of $\mathrm{Cr}, \mathrm{Ni}, \mathrm{Mo}$, $\mathrm{Mn}, \mathrm{Fe}, \mathrm{C}$ (a); grain size distribution of second phases (b) (the measured area was about $3.64 \times 10^{4} \mu \mathrm{m}^{2}$ ) 


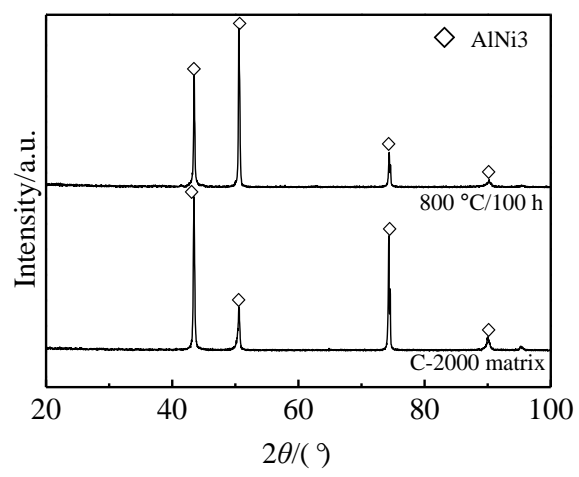

Fig.2 XRD patterns of C-2000 matrix and alloy after oxidation at $800{ }^{\circ} \mathrm{C}$ for $100 \mathrm{~h}$ in air

be enriched in areas of some defects such as vacancy, dislocation and stress concentration. Although the thermal conductivity of the same element is same, its diffusion is anisotropic, which leads to a difference of length of diffusion path and loss of heat. Finally, the heat difference will affect the morphology of precipitation phases.

\subsection{TEM image of alloy matrix after oxidation}

Bright-field image and corresponding selected area electron diffraction of second phases are given in Fig.3. Chemical compositions of second phases (wt $\%$ ) are $28.66 \mathrm{Ni}, 19.60 \mathrm{Cr}$ and 51.74Mo (Fig.3b), which is consistent with the results of SEM-EDS. Liu et al. ${ }^{[20]}$ reported that the $\mathrm{M}_{6} \mathrm{C}$ (chemical formula is $\mathrm{A}_{3} \mathrm{~B}_{3} \mathrm{C}$, where $\mathrm{A}$ is $\mathrm{Fe}$, Ni element and $\mathrm{B}$ is $\mathrm{Mo}$

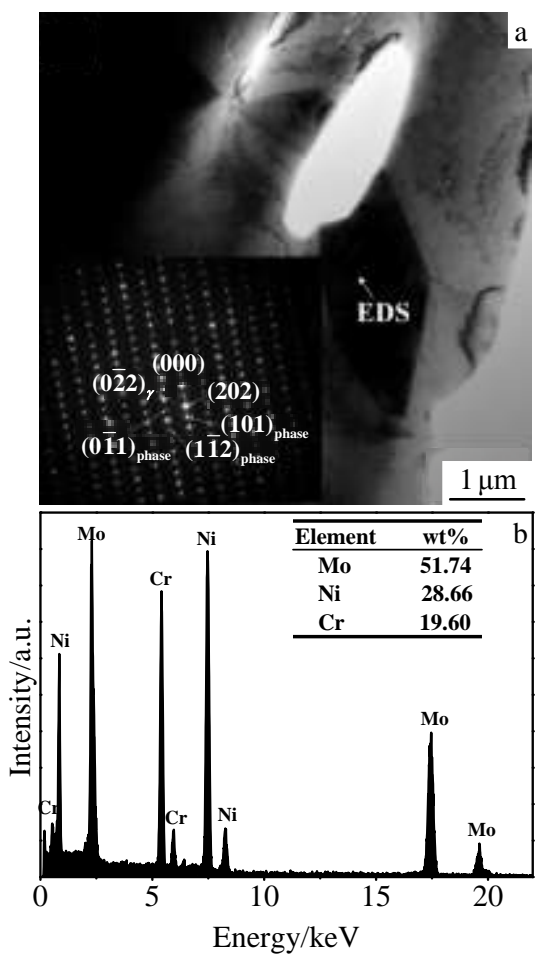

Fig.3 Typical TEM image (a) and EDS spectrum (b) of the second phase element) type carbides are easy to form during aging heat treatment when nickel-base superalloys contain high Mo contents. It was determined that Mo-rich phases are $\mathrm{Mo}_{3} \mathrm{Ni}_{3} \mathrm{C}$ type carbides $\left(\mathrm{M}_{6} \mathrm{C}\right)$ with a diamond cubic structure by both chemical component and SAED. No other types of carbides ( $\mathrm{MC}, \mathrm{M}_{7} \mathrm{C}_{3}$ and $\mathrm{M}_{23} \mathrm{C}_{6}$ ) appear in the alloy matrix, because, the stability of $\mathrm{MC}$ decreases when $\mathrm{W}$ and $\mathrm{Mo}$ atoms enter $\mathrm{MC}$ so that its degeneration occur, and the decomposition product of $\mathrm{MC}$ is $\mathrm{M}_{6} \mathrm{C} . \mathrm{M}_{7} \mathrm{C}_{3}$ mainly appear in Co-based superalloy, and it can only precipitate above $1000{ }^{\circ} \mathrm{C}$ in the $\mathrm{Ni}$-Cr-based alloy. $\mathrm{M}_{23} \mathrm{C}_{6}$ is transformed into $\mathrm{M}_{6} \mathrm{C}$ due to the instability characteristic at the test temperature. The corrosion pits with diamond cubic structure has further proved that the Mo-rich phase is $\mathrm{M}_{6} \mathrm{C}$ type carbides (Fig.4c).

\subsection{SEM-BSE images of alloy matrix after deep etching}

Fig.4 represents SEM-BSE images of alloy matrix after deep etching. It can be seen that small corrosion pits with diamond cubic structure characteristic appears in grains (Fig.4c-M), and second phases with flocculent structure are distributed along grain boundaries (Fig.4d-P). In addition, a few needle-like residual phases also show some small pits (Fig.4c-N). EDS spectra show that main element contents are basically the same at both polygonal pits and alloy matrix, which indicates that original phases has been completely corroded so that alloy matrix is exposed out. However, Ni and Mo contents of needle-like phases decrease and increase, respectively in both pits and grain boundaries. In addition, grain boundaries are significantly broadened and deepened after deep etching resulting from depletion of elements on the grain boundaries. It is well known that the precipitation of $\mathrm{Mo}_{3} \mathrm{Ni}_{3} \mathrm{C}$ type carbides on the grain boundary can lead to

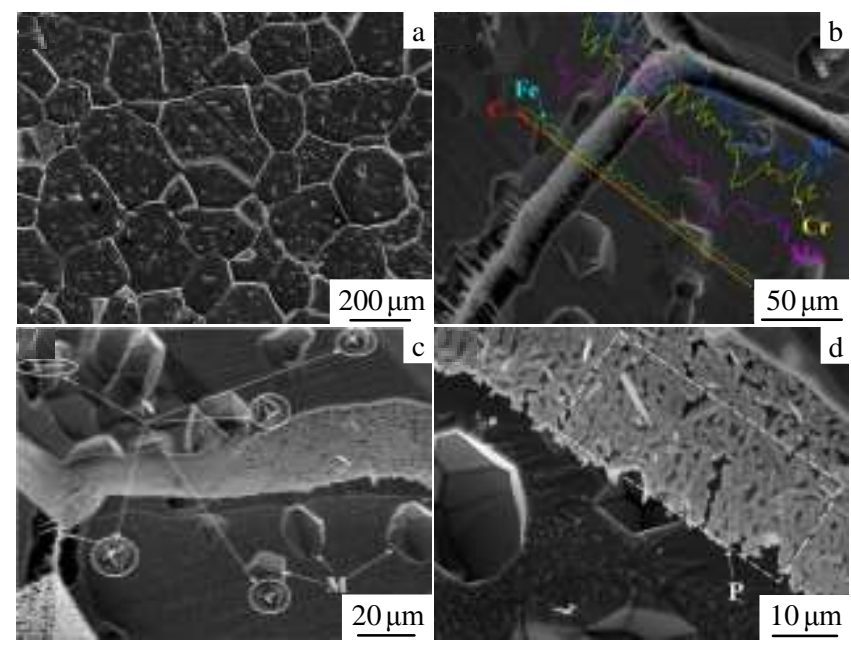

Fig.4 SEM-BSE images of the alloy after deep etching: (a) alloy matrix; (b) element line scanning of $\mathrm{Ni}, \mathrm{Cr}, \mathrm{Mo}, \mathrm{Fe}, \mathrm{C}$ cross grain boundaries; (c) small corrosion pits with diamond cubic structure characteristic in grains, and a few needle-like residual phases; (d) second phases with flocculent structure distributed along grain boundaries 
depletion of Mo and Ni elements, and thus the corrosion resistance of alloy at the grain boundary are deteriorated.

Second phases have different chemical compositions from the alloy matrix, which lead to different chemical and physical properties. The standard electrode potential of $\mathrm{Ni}, \mathrm{Cr}$ and $\mathrm{Mo}$ is $-0.25 \mathrm{~V},-0.913 \mathrm{~V}$ and $-0.2 \mathrm{~V}$ at $25^{\circ} \mathrm{C}$, respectively ${ }^{[21]}$; therefore, $\mathrm{Ni}$ and $\mathrm{Cr}$ will take priority to corrode compared with Mo. Impurity atoms are apt to enrich in grain boundaries due to disordered arrangement of atomic in grain boundaries. As a result, grain boundaries are such more active that a more negative electrode potential is obtained, i.e. it is more susceptible to corrode. In addition, the enriching effects of $\mathrm{Ni}$ and $\mathrm{Cr}$ elements induce the local deformation of lattice, which produce stress field and prompt electrode potential to more negative value. As a result, some small pits appear in areas of rich $\mathrm{Ni}$ and $\mathrm{Cr}$ after deep etching. Bubbles continuously appear in corrosion solution during deep etching because the cathodic reaction is mainly a hydrogen depolarization. Furthermore, it may be attributed to phenomenon of dark green solution to generation of $\mathrm{Ni}^{2+}, \mathrm{Cr}^{3+}$ or a small amount of $\mathrm{Fe}^{2+}$ ions after anodic corrosion.

\section{Conclusions}

1) Mo-rich phases can be precipitated in Hastelloy C-2000 alloy matrix after oxidation at $800{ }^{\circ} \mathrm{C}$ for $100 \mathrm{~h}$ in air, which change the chemical distribution of alloying elements in different regions as well as areas of $\mathrm{Ni}$ and $\mathrm{Cr}$-rich appear in alloy matrix.

2) Mo-riched phases with diamond cubic structure are $\mathrm{Mo}_{3} \mathrm{Ni}_{3} \mathrm{C}$ type carbides.

3) Areas of $\mathrm{Ni}$ and $\mathrm{Cr}$-rich are more easily corroded in the testing solution due to a more negative electrode potential in these areas.

\section{References}

1 Kim Hojong, Mitton D B, Latanision R M. Corrosion Science[J], 2010, 52: 801

2 Zhang Qiang, Tang Rui, Yin Kaiju et al. Corrosion Science[J],
2009, 51: 2092

3 McDaniels R L, Chen L, Steward R et al. Materials Science and Engineering $A[\mathrm{~J}], 2011,528: 3952$

4 Al-Hatab K A, Alariqi F S, Al-Bukhaiti M A et al. Oxidation of Metals[J], 2011, 76: 385

5 Loeffel Kaspar, Anand Lallit, Gasem Zuhair M. Acta Materialia [J], 2013, 61: 399

6 Lang Fengqun, Narita Toshio. Intermetallics[J], 2007, 15: 599

7 Zhou Y B, Sun J F, Wang S C et al. Corrosion Science[J], 2012, 63: 351

8 Kihara S, Newkirk J, Ohtomo A. Metallurgical and Materials Transactions A[J], 1980, 6: 1019

9 Pai H C, Sundararaman M, Maji B C. et al. Journal of Alloys and Compounds[J], 2010, 491: 159

10 Chatterjee Sudin, Roy Ajit K. Materials Science and Engineering $A[\mathrm{~J}], 2010,527: 7893$

11 Zagal J M, López H F, Flores O. Corrosion Science[J], 2008, 50: 3371

12 Tawancy H M, Aboelfotoh M O. Materials Science and Engineering $A[\mathrm{~J}], 2009$, 500: 188

13 Casales M, Salinas-Bravo V M, Martinez-Villafñe A et al. Materials Science and Engineering A[J], 2002, 332: 223

14 Sahlaoui H, Sidhom H, Philibert J. Acta Materialia[J], 2002, 50: 1383

15 Berthod P, Vebert C, Aranda L et al. Oxidation of Metals[J], 2005, 63(112): 57

16 Yang Ruicheng, Jin Saite, Lu Xuefei et al. Transactions of Materials and Heat Treatment[J], 2009, 30(1): 24

17 Zheng Lei, Guido Schmitz, Ye Meng et al. Critical Reviews in Solid State and Materials Sciences[J], 2012, 37: 181

18 Zheng Lei, Reda Chellali, Ralf Schlesiger et al. Scripta Materialia[J], 2011, 65: 428

19 Lisoni J G, Goux L, Hoffmann Th et al. Corrosion Science[J], 2012, 59: 282

20 Liu L R, Jin T, Zhao N R et al. Mater Lett[J], 2003, 57(29): 4540

21 Wei Baoming. Corrosion Theory and Application[M]. Beijing: Chemical Industry Press, 2008: 19 (in Chinese)

\title{
哈氏 C-2000 合金在等温氧化时第二相沉淀析出行为
}

\author{
袁 亮, 胡 锐, 张铁邦, 薛祥义, 李金山 \\ (西北工业大学 凝固技术国家重点实验室，陕西 西安 710072)
}

\begin{abstract}
摘 要: 研究了哈氏 C-2000 合金在 $800{ }^{\circ} \mathrm{C} / 100 \mathrm{~h}$ 空气中等温氧化后合金基体中第二相的沉淀行为。氧化后基体中析出了富 Mo 相, 可 确定该富 $\mathrm{Mo}$ 相为具有金刚石结构的 $\mathrm{Mo}_{3} \mathrm{Ni}_{3} \mathrm{C}$ 型碳化物。富 $\mathrm{Mo}$ 相沿晶界和晶内分别呈现出非连续和连续条状形貌特征。然而, 经深腐 蚀后, 晶内和晶界处形貌均发生了变化, 即, 沿晶界出现了大量白色絮状物, 晶内则出现了具有金刚石结构的腐蚀坑。由于富 $\mathrm{Ni}$ 和富 Cr 区域具有更负的电极电位，因而使得这些区域在深腐蚀后更易被侵蚀。
\end{abstract}

关键词: 氧化; 富 $\mathrm{Mo}$ 相; $\mathrm{Mo}_{3} \mathrm{Ni}_{3} \mathrm{C}$ 型碳化物; 晶界; 电极电位

作者简介：袁 亮，男，1983 年生，博士生，西北工业大学凝固技术国家重点实验室，陕西 西安 710072, 电话: 029-88491764, E-mail: yuanliang031@163.com 